\title{
Screening of antimicrobial activity of lactic acid bacteria isolated from anango baca slurry, a spontaneously fermented maize product used in Côte d'Ivoire
}

\author{
Solange AKA-GBEZO ${ }^{1,2^{*}}$, Amoin Georgette KONAN ${ }^{2,3}$, Mathias N'CHO ${ }^{1}$, \\ Patricia ACHI ${ }^{1,2}$, Rose KOFFI-NEVRY ${ }^{1}$, Marina KOUSSEMON-CAMARA ${ }^{1}$ and \\ Bassirou BONFOH ${ }^{2}$ \\ ${ }^{1}$ Laboratoire de Biotechnologie et Microbiologie des Aliments, UFR des Sciences et Technologies des \\ Aliments, Université Nangui Abrogoua, 02 BP 801 Abidjan 02, Côte d'Ivoire. \\ ${ }^{2}$ Centre Suisse de Recherches Scientifiques en Côte d'Ivoire, Abidjan, BP 1303 Abidjan 01, Côte d'Ivoire. \\ ${ }^{3}$ Laboratoire de Biochimie et Sciences des Aliments, UFR Biosciences, Université Félix Houphouët-Boigny- \\ Abidjan, 22 B P V 582 Abidjan 22, Côte d'Ivoire. \\ *Corresponding author; E-mail: solangeakan@yahoo.fr; Tel.: +2250571 6832.
}

\section{ACKNOWLEDGMENTS}

Financial support for this research was provided by the Centre Suisse de Recherches Scientifiques en Côte d'Ivoire (CSRS) through Afrique One Consortium Programme. The authors would like to express their sincere gratitude to this institution.

\begin{abstract}
Anango baca is a traditional porridge-like food product made from fermented maize slurry which is widely used as a complementary food for infants in Côte d'Ivoire. The present study was conducted to assess antimicrobial activities of lactic acid bacteria (LAB) from this fermented infant's product. Thereby, LAB were isolated into the slurry and their antimicrobial effects were examined via agar spot test and agar diffusion method prior to their identification by molecular tools. Anango baca slurry was found to be acidic ( $\mathrm{pH}$ between $2.98 \pm 0.02$ and $3.75 \pm 0.01$ ). Counts of mesophilic LAB from MRS agar and thermophilic LAB varied from $6.4 \pm 0.6 \log$ UFC. $g^{-1}$ to $10.9 \pm 0.5 \log$ UFC. $g^{-1}$ and from $5.6 \pm 2.3 \log$ UFC.g ${ }^{-1}$ to $10.6 \pm 0.5 \log$ UFC.g ${ }^{-1}$, respectively. Thirteen $\mathrm{LAB}$ produced antibacterial substances able to inhibit the growth of pathogens and foodborne spoilage indicator bacteria. They were identified as Lactobacillus fermentum (46\%), L. plantarum (23\%), Enterococcus faecium (23\%) and Staphylococcus pasteuri (8\%). Among them, E. faecium and S. pasteuri produced bacteriocins. However, these bacteria are considered sometimes to be opportunistic pathogens. Thus, fermented maize slurry production must be to do from LAB selected to improve the hygiene and safety of anango baca slurry and also children's health. Further studies will be conducted to select LAB able to be used as starters.

(C) 2017 International Formulae Group. All rights reserved.
\end{abstract}

Keywords: Anango baca slurry, lactic acid bacteria, fermented maize porridge, antimicrobial activity, bacteriocin, molecular identification.

\section{INTRODUCTION}

Many food products are obtained by lactic fermentation using selected probiotic lactic acid bacteria such as Bifidobacterium bifidum, Bifidobacterium lactis,

Bifidobacterium longum, Streptococcus thermophilus, Lactobacillus rhamnosus, Lactobacillus bulgaricus, Lactobacillus 
acidophilus (Butler et al., 2012). Alongside these controlled fermentations, there are also spontaneous fermentations which are widely used in Africa for centuries to preserve and improve the shelf-life of foods and their nutritional value. Moreover, spontaneous fermentation has been shown to reduce the risk of foodborne illness and to reduce and prevent diarrhoea in children (Lei and Jacobsen, 2004; Achi and Ukwuru, 2015). Lactic acid bacteria (LAB) involved in these spontaneous fermentations can have probiotic properties (Franz et al., 2014). In West Africa, the spontaneous lactic acid fermentation of cereal-based is widespread to produce many weaning foods such ben-saalga in BurkinaFaso, koko in Ghana, ogi in Nigeria, baca, coco-baca and anango-baca. in Côte d'Ivoire (Lei and Jacobsen, 2004; Falegan et al., 2014; Soro-Yao et al., 2014; Kouakou et al., 2016). Anango baca is a traditional porridge from fermented maize slurry. It constitutes an example of traditional complementary food given to infants as early as at 2 months of age. Depending on the age of the infant, the consistence of anango baca ranges from very liquid slurry, used as complementary food for infants of 2 years of age and younger, to a semi-solid slurry for older children. This porridge is sometimes comsumed for breakfast or as staple food for young people and adults. The anango baca is similar to ogi but poorly documented in Côte d'Ivoire. The anango baca production starts by steeping maize grains in warm water for one day followed by wet milling and sieving through a screen mesh after the addition of water. The sieved material is allowed to sediment and ferment for 24-72 hours. The liquid top-layer from the decantation is subsequently boiled for 1-2 hours and the sedimented bottomlayer is added until the desired consistency is obtained. The final consumable product is obtained by adding powdered milk with or without sugar. This weaning porridge has a specific yoghurt-like sour flavor that distinguishes it from every other fermented cereal-based food.

LAB found in traditional fermented products exhibit sometimes antibacterial activities against spoilage bacteria and food- borne pathogens (Achi and Ukwuru, 2015). The antibacterial activity of these organisms is based on their ability to produce a variety of antimicrobial substances such as diacetyl, acetone, ethanol, carbon dioxide, organique acids, hydrogen peroxide and bacteriocins (Falegan et al., 2014; Achi and Ukwuru, 2015). The anango baca slurry is commonly found on the market where some mothers purchase it to feed their infant. Several mothers prefer to produce their own for economic reasons. However, the traditional home-based production methods present some health risk due the lack of adequate hygene and safety conditions. To improve the production method, it would be ideal to use starter cultures made from LAB involved in the spontaneous fermentation of anango baca slurry. Production using such starter cultures conducted under the appropriated hygiene and safety standards could help reducing diarrheal diseases and thus ensure the well-being of children 0 to 5 years old. The objective of this work was therefore to identify and characterize $\mathrm{LAB}$ isolated from anango baca slurry, able to inhibit the growth of pathogens and food spoilage microorganisms.

\section{MATERIALS AND METHODS \\ Collection of samples}

Samples of anango baca slurry were obtained from five volunteer mothers randomly selected who produce this fermented maize slurry in the district of Yopougon located in the district of Abidjan, Côte d'Ivoire. Approximately $250 \mathrm{~g}$ of samples were taken and transferred into sterile bottles, labelled and subsequently transported to the laboratory in a coolbox. Sampling was done five times from each of these women resulting in a total of 25 anango baca slurry samples. 


\section{Chemical analysis}

Ten grammes of anango baca slurry were mixed with $90 \mathrm{ml}$ of distilled water prior to $\mathrm{pH}$ measurement using a Sension $\mathrm{TM}+$, MM340 pH meter. Two independent measurements were made for each sample.

\section{Microbiology analysis}

A total of $10 \mathrm{~g}$ of each sample were added into $90 \mathrm{ml}$ of sterile buffer peptone water (BPW, Oxoid, UK) and homogenized in a stomacher (Colworth 400, UK) for $30 \mathrm{~s}$ at normal speed. Subsequently, $10 \mathrm{ml}$ of mixture obtained were aseptically added into $90 \mathrm{ml}$ of sterile BPW medium and mixed. Serial dilutions $\left(10^{-1}\right.$ to $\left.10^{-7}\right)$ were performed and a $0.1 \mathrm{ml}$ aliquot of the appropriate dilution was directly inoculated in duplicate on Man Rogosa Sharpe agar (MRS, AFNOR, NF ISO 15214). Plates were subsequently incubated at $30{ }^{\circ} \mathrm{C}$ and $45^{\circ} \mathrm{C}$ for $48 \mathrm{~h}$ under anaerobic conditions using anaerobic jars for counting the mesophilic and thermophilic LAB. LAB were also counted on Bile Esculin Azide agar (BEA, NF ISO 7899/1) at $37{ }^{\circ} \mathrm{C}$ for $48 \mathrm{~h}$. A total of 235 isolates of $\mathrm{LAB}$ were randomly selected and characterized based on cell morphology, catalase and oxidase tests. Cultures were stored at $-80{ }^{\circ} \mathrm{C}$ in MRS broth containing $20 \%$ glycerol. Prior to the experiments, cultures were propagated twice in MRS at $37{ }^{\circ} \mathrm{C}$; the transfer inoculum was $1 \%(\mathrm{v} / \mathrm{v})$ of $16 \mathrm{~h}$ culture grown in fresh medium.

\section{Antimicrobial activity}

Antimicrobial activity was investigated against indicator bacteria using agar spot tests and the well diffusion assay as described by Kivanç et al. (2011). The indicator bacteria strains were obtained from culture collections of the Laboratoire National de la Santé Publique and the Microbiology Laboratory of the Centre Suisse de Recherches Scientifiques en Côte d'Ivoire (CSRS). The media and cultivation conditions used for antibacterial activities are presented in Table 1. Agar spot test experiments were conducted by spotting $10 \mathrm{ml}$ of $16 \mathrm{~h} \mathrm{LAB}$ cultures onto the surface of a modified MRS agar plate and incubating anaerobically in an anaerobic jar at $37{ }^{\circ} \mathrm{C}$ for $24 \mathrm{~h}$ to allow colonies to develop. Each indicator strain was cultured in $10 \mathrm{ml}$ of nutrient broth (Difco) at $37{ }^{\circ} \mathrm{C}$ overnight for $16 \mathrm{~h}$. Subsequently, $100 \mu \mathrm{l}$ of overnight culture of each indicator strain were inoculated into $7 \mathrm{ml}$ of soft nutrient agar (0.7\% agar) maintained at $45{ }^{\circ} \mathrm{C}$ and poured over the modified MRS plates on which the tested strains were grown. The plates were incubated again aerobically at $37{ }^{\circ} \mathrm{C}$. The sizes of the inhibition zones were measured after $24 \mathrm{~h}$ of incubation and re-measured after $48 \mathrm{~h}$. The inhibition was scored positive if the width of the clear zone around the colonies of the tested strains was $1 \mathrm{~mm}$ or larger. Antibacterial tests were carried out in triplicate and the mean values recorded.

For the agar well diffusion assay, test strains were inoculated in MRS broth. After incubation at $37{ }^{\circ} \mathrm{C}$ for $24 \mathrm{~h}$, cultures were centrifuged and cell-free supernatants (CFS) were subjected to three different processes: (I) unneutralized, (II) neutralized by addition of $\mathrm{NaOH} 5 \mathrm{~N}$ to exclude the effects of organic acids ( $\mathrm{pH}$ 6.5) and (III) treated neutralized supernatants with catalase (catalase from bovine liver, C100-500MG, Sigma-Aldrich, Germany) to a final concentration of $1 \mathrm{mg} \cdot \mathrm{ml}^{-1}$ for $1 \mathrm{~h}$ at $25{ }^{\circ} \mathrm{C}$ to exclude inhibitory effects of hydrogen peroxide. The different supernatants were filtered through a $0.22 \mu \mathrm{m}$ Millipore sterile filter (Corning syringe filters, Sigma-Aldrich, Germany). An aliquot of $60 \mu \mathrm{l}$ of the final supernatant was filled in Brain Heart Infusion (BHI) or nutrient or MRS soft agar (0.9\% agar) plate seeded with active growing cells of the pathogenic indicator bacteria (approximately $10^{6} \mathrm{CFU}^{\mathrm{m} \mathrm{ml}^{-1}}{ }^{-}$. The plates were pre-incubated at $4{ }^{\circ} \mathrm{C}$ for $2 \mathrm{~h}$ and then incubated at $18 \mathrm{~h}$ at 37 ${ }^{\circ} \mathrm{C}$ or $42.5{ }^{\circ} \mathrm{C}$ and checked for inhibition 
zones which were measured in diameter $(\mathrm{mm})$. Triplicate trial assays were performed. After eliminating organic acid function and hydrogen peroxide, the cell free culture supernatants still retaining antimicrobial activity were selected out to determine the possible protein nature of the detected antimicrobial substances. Proteinase K (1 $\mathrm{mg} \cdot \mathrm{ml}^{-1}$ final concentration) was added to the neutralized supernatants from cell free cultures (in the storage buffer $0.05 \mathrm{M}$ Tris hydrochloride, $\mathrm{pH} 7.5,0.01 \mathrm{M} \mathrm{CaCl}_{2}, 50 \mathrm{ml}$ glycerol, adding of Milli Q water until 100 $\mathrm{ml})$. After incubation at $37^{\circ} \mathrm{C}$ for $1 \mathrm{~h}$, the test tubes were heated at $80{ }^{\circ} \mathrm{C}$ for $10 \mathrm{~min}$ to inactivate the enzyme and the antimicrobial activities were assayed as described above.

\section{Molecular identification \\ DNA extraction}

DNA from 13 LAB isolates was extracted and purified by means of a phenol/chloroform extraction method as described previously by Lopez et al. (2003).

\section{PCR amplification and sequencing}

The $16 \mathrm{~S}$ ribosomal gene was amplified with universal primers used by Henk et al. (2008): 27F $\quad 27$ AGAGTTTGATCCTGGCTCAG-3') and WLAB2R

\section{TCGAATTAAACCACATGCTCCA-3').}

PCR was performed using a final volume of $50 \mu$ containing $5 \mu$ l of $10 \mathrm{X}$ Ex-Taq buffer (20 mM Tris- $\mathrm{HCl}, 100 \mathrm{mM} \mathrm{KCl}, 20 \mathrm{mM}$ $\mathrm{MgCl}_{2}$, Takara Bio Inc.), $5 \mu \mathrm{l}$ of dNTP (2.5 mM of each dATP, dCTP, dGTP and dTTP), $5 \mu \mathrm{l}$ of each primer $\left(10 \mathrm{pmol} \mu \mathrm{l}^{-1}\right), 0.125 \mu \mathrm{l}$ of Ex-Taq (Takara Bio Inc.) and $5 \mu$ of the extracted DNA (approximately $50 \mathrm{ng}$ ). The amplification program consisted of initial one denaturation step of $95{ }^{\circ} \mathrm{C}$ for 5 min followed by 35 amplification cycles of $94{ }^{\circ} \mathrm{C}$ for $30 \mathrm{~s}$, $55{ }^{\circ} \mathrm{C}$ for $30 \mathrm{~s}$ and $72{ }^{\circ} \mathrm{C}$ for $30 \mathrm{~s}$ and a final extension step of $72{ }^{\circ} \mathrm{C}$ for $5 \mathrm{~min}$ using a
GeneAmp thermalcycler (GeneAmp PCR System 9700; PE Applied Biosystems, Foster City, California, USA). Amplicons were run on $1 \%$ agarose gels, stained with ethidium bromide, visualized under UV light and photographed with a tansillumination cabinet (Fisher). Before sequencing, amplified products were purified with Exonuclease I (20 U.ml ${ }^{-1}$ ) and SAP (Shrimp Alkaline Phosphatse, 1 U. $\mu l^{-1}$ ) and sent to Eurofins (Paris, France) for sequencing. LAB identities were obtained using online BLAST program (https://blast.ncbi.nlm.nih.gov/Blast.cgi). For phylogeny, 16S rRNA sequences were aligned with MUSCLE (Multiple Sequence Comparison by Log-Expectation) (Edgard, 2004), and unreliable positions were curated using Gblocks (Castresana, 2000). A maximum likelihood tree was generated by PhyML, using the GTR (General Time Reversible) nucleotide substitution model (Guindon et al., 2010) and allowing 4 rate substitution categories. A Confidence value for the branching order was generated by bootstrapping (based on 100 replications). Escherichia coli was used as an outgroup organism.

\section{Statistical analysis}

Data of slurry $\mathrm{pH}$ and LAB counts were analysed using one-way analysis of variance (ANOVA) (statistical, 99 ${ }^{\text {th }}$ edition). Duncan's multiple range test was used to compare the means when a significant variation was established by ANOVA at the significance level $(\alpha=0.05)$. The Principal Component Analysis (PCA) was carried out on the LAB species exhibiting antibacterial activity found into anango baca slurry samples from mothers. The Software XLSTAT (Version Adinosoft Inc.) was used. PCA was used to reduce the initial variables into new components, called factors, to summarize the information. 
Table 1: Media and culture conditions of indicator bacteria strains used for antibacterial activity.

\begin{tabular}{lll}
\hline Indicator bacteria strains & Sources & Media and culture conditions \\
\hline Bacillus subtilis & CIP 7718 & Nutrient broth, $18-24 \mathrm{~h}, 37^{\circ} \mathrm{C}$ \\
Bacillus cereus & DSM $31^{\mathrm{T}}$ & Nutrient broth, $18-24 \mathrm{~h}, 37^{\circ} \mathrm{C}$ \\
Bacillus thuringensis & DSM $2046 \mathrm{~T}$ & Nutrient broth, $18-24 \mathrm{~h}, 37^{\circ} \mathrm{C}$ \\
S. aureus & ATCC 481 & Nutrient broth, $18-24 \mathrm{~h}, 37^{\circ} \mathrm{C}$ \\
Staphylococcus aureus & ATCC 25923 & Nutrient broth, $18-24 \mathrm{~h}, 37^{\circ} \mathrm{C}$ \\
Listeria innocua & ATCC 33090 & Nutrient broth, $18-24 \mathrm{~h}, 37^{\circ} \mathrm{C}$ \\
Enterococcus faecalis & CIP 105042 & BHI, $18-24 \mathrm{~h}, 37^{\circ} \mathrm{C}$ \\
Enterococcus faecium & ATCC 51558 & BHI, $18-24 \mathrm{~h}, 37^{\circ} \mathrm{C}$ \\
Enterococcus faecalis & Clinical LNSP & BHI, $18-24 \mathrm{~h}, 37^{\circ} \mathrm{C}$ \\
Streptococcus sp & Clinical LNSP & BHI, 18-24 h, $37^{\circ} \mathrm{C}$ \\
Lactobacillus delbrueckii & F 31 & MRS, $18-24 \mathrm{~h}, 42.5{ }^{\circ} \mathrm{C}$, anaerobiosis \\
Salmonella typhi & ATCC50157 & Nutrient broth, $18-24 \mathrm{~h}, 37^{\circ} \mathrm{C}$ \\
Salmonella typhi & ATCC 5066 & Nutrient broth, $18-24 \mathrm{~h}, 37^{\circ} \mathrm{C}$ \\
Escherichia coli & ATCC 28170 & Nutrient broth, $18-24 \mathrm{~h}, 37^{\circ} \mathrm{C}$ \\
Escherichia coli & ATCC 25922 & Nutrient broth, $18-24 \mathrm{~h}, 37^{\circ} \mathrm{C}$ \\
Pseudomonas aeruginosa & ATCC 27853 & Nutrient broth, $18-24 \mathrm{~h}, 37^{\circ} \mathrm{C}$ \\
Pseudomonas aeruginosa MRIPCI & Clinical LNSP & Nutrient broth, $18-24 \mathrm{~h}, 37^{\circ} \mathrm{C}$ \\
\hline
\end{tabular}

\section{RESULTS}

pH of slurry and LAB counts

The lowest $\mathrm{pH}$ of fermented maize slurry samples was observed in the samples obtained from mother 4 among the five volunteer mothers $(\mathrm{pH} 2.98 \pm 0.02)$ and the highest $\mathrm{pH}$ value was observed with samples derived from mother $1(\mathrm{pH} 3.75 \pm 0.01 ; \mathrm{P}<$ 0.05) (Table 2). Counts of mesophilic LAB from MRS agar and thermophilic LAB varied significantly from $6.4 \pm 0.6 \log$ UFC. ${ }^{-1}$ to $10.9 \pm 0.5 \log$ UFC. $\mathrm{g}^{-1}$ and from $5.6 \pm 2.3 \log$ UFC. $\mathrm{g}^{-1}$ to $10.6 \quad \pm \quad 0.5 \quad \log \quad$ UFC. $\mathrm{g}^{-1}$, respectively. Those of mesophilic LAB from BEA agar varied from $5.5 \pm 3.2 \log$ UFC. ${ }^{-1}$ to $9.4 \pm 0.8 \log \mathrm{UFC}^{-\mathrm{g}^{-1}}$. LAB counts varied significantly $(\mathrm{P}<0.05)$ between mediums and incubation temperature.

\section{Antibacterial activity}

A total of 235 LAB isolates randomly selected were investigated for their antimicrobial activity against different spoilage and food borne pathogens by the agar spot method. Among them, 27 other strains had inhibitory effect against Escherichia coli ATCC 28170 and E. coli ATCC 25922 (results not shown). Twenty strains showed antimicrobial activity against Salmonella typhi ATCC 5066 and S. typhi ATCC 50157 and 9 strains against Pseudomonas aeruginosa MRIPCI and P. aeruginosa ATCC 27853. Eight strains had inhibitory effect against Listeria innocua ATCC 33090, Enterococcus faecalis CIP 105042, E. faecium ATCC 51558 and E. faecalis. A total of 7 strains showed 
antimicrobial activity against Bacillus thuringensis DSM $2046^{\mathrm{T}}$, B. subtilis CIP 7718 and Lactobacillus delbrueckii F/31. However, 188 isolates did not show any inhibitory activity against the indicator microorganisms. A total of 47 isolates $(20 \%)$ demonstrated antimicrobial activity against at least one of indicator spoilage or food borne pathogens.

The identified 47 LAB strains were secondly screened for bacteriocin production by the well-diffusion method against the same indicator bacteria described above. The results showed that unneutralized cell-free supernatants (CFSs) of LAB exhibited antimicrobial activity against at least one of indicator spoilage or food borne pathogens (Table 3). About 20 LAB CFSs had inhibitory effect against $S$. typhi ATCC 5066, S. typhi ATCC 50157, E. coli ATCC 28170 and E. coli ATCC 25922 with the diameter of inhibition zone ranged from 7 to $21 \mathrm{~mm}$ (Figure 1). Moreover, 15 LAB CFSs had also inhibitory effect against $L$. delbrueckii $\mathrm{F} / 31$. Streptococcus sp, S. aureus ATCC 481 and $L$. innocua ATCC 33090 were inhibited by 13 LAB CFSs.

After eliminating organic acid function ( $\mathrm{pH}$ was neutralized), most of LAB CFSs had no antimicrobial activity and only 13 LAB CFSs still exhibited inhibitory activity against one or more of indicators strains (Table 3). After catalase treatment, only four strains kept their entire inhibitory activity against $L$. innocua ATCC 33090, $E$. faecalis CIP 105042, E. faecium ATCC 51558, E. faecalis, Streptococcus $s p$ and $L b$. delbrueckii F/31. Gram-negatif indicators resisted to inhibitory effect of neutralized LAB CFSs treated with catalase (Table 3). However, the activity of the supernatants from these four LAB CFSs was destroyed after treatment with proteinase $\mathrm{K}$ confirming that these inhibitory compounds are of proteinaceous nature so the bacteriocins compounds.

\section{LAB identified}

The 13 LAB whose CFSs had inhibitory activity against indicators were characterized by PCR. PCR products expected were about 900 base pairs (Figure 2). Amplicons were identified by $16 \mathrm{~S}$ sequencing as L. fermentum, L. plantarum, E. faecium and Staphylococcus pasteuri. L. fermentum (46\%) represented the largest percentage, followed by $L$. plantarum $(23 \%)$ and E. faecium $(23 \%)$ (Figure 2). The four bacteria which produced bacteriocins have been identify as E. faecium (three) and S. pasteuri (one). Figure 3 showed the distribution of the $13 \mathrm{LAB}$ species isolated in the anango baca slurry samples from the five mothers. The F1 and F2 axes retained after the ACP allowed to explain $99.38 \%$ of the data, with $66 \%$ for the first component (F1). The F1 axis contrasted L. fermentum with a positive correlation to E. faecium and $S$. pasteuri. Samples of mother 1 and mother 2 were also positively correlated to F1. The F2 axis opposed $L$. plantarum to samples of mother 3. Thereby, samples of mother 1 and mother 2 were characterized by a strong presence of $L$. fermentum in contrast to $E$ faecium and $S$. pasteuri which were present in small proportions. Samples of mother 3 did not contain L. plantarum. The distribution of species was variable and depended on the Mothers. LAB species exhibiting antibacterial activity were not found into anango baca slurry samples from mothers 4 and 5 .

The phylogenetic relationships of the different strains was determined from their 16S rRNA gene sequences, relative to other selected 16S rRNA gene sequences obtained from the National Center for Biotechnology Information database (Figure 4). Escherichia coli was used as an outgroup organism. Four clusters were observed corresponding to the four species involved in anango baca slurry. The strains were phylogenetically close regardless of the sampling site. 
S. AKA-GBEZO et al. / Int. J. Biol. Chem. Sci. 11(6): 2616-2629, 2017

Table 2: Counts of LAB isolated from fermented slurry maize samples.

\begin{tabular}{|c|c|c|c|c|c|c|c|c|}
\hline \multirow[t]{2}{*}{$\begin{array}{l}\text { Different } \\
\text { mothers }\end{array}$} & \multicolumn{2}{|c|}{ pH value } & \multicolumn{2}{|c|}{$\begin{array}{l}\text { Mesophilic LAB isolated } \\
\text { on MRS agar } \log \left(\mathrm{CFU} . \mathrm{g}^{-1}\right)\end{array}$} & \multicolumn{2}{|c|}{$\begin{array}{l}\text { Thermophilic LAB isolated } \\
\text { on MRS agar } \log \left(\mathrm{CFU} . \mathrm{g}^{-1}\right)\end{array}$} & \multicolumn{2}{|c|}{$\begin{array}{l}\text { Mesophilic LAB isolated } \\
\text { on BEA agar } \log (\text { CFU.g } \\
\text { (1) }\end{array}$} \\
\hline & Mean & SD & Mean & SD & Mean & SD & Mean & SD \\
\hline Mother 1 & $3.75^{\mathrm{a}}$ & 0.01 & $9.4^{\mathrm{a}}$ & 0.8 & $7.4^{b}$ & 4.3 & $9.4^{\mathrm{a}}$ & 0.8 \\
\hline Mother 2 & $3.7^{\mathrm{a}}$ & 0.02 & $6.4^{\mathrm{a}}$ & 0.6 & $5.6^{\mathrm{ab}}$ & 2.3 & $5.5^{\mathrm{b}}$ & 3.2 \\
\hline Mother 3 & $3.3^{\mathrm{ab}}$ & 0.01 & $10.9^{\mathrm{a}}$ & 0.5 & $10.1^{\mathrm{b}}$ & 1.3 & $9.1^{\mathrm{c}}$ & 3.5 \\
\hline Mother 4 & $2.98^{\mathrm{b}}$ & 0.02 & $10.7^{\mathrm{a}}$ & 0.6 & $10.2^{\mathrm{a}}$ & 0.6 & $8.1^{\mathrm{b}}$ & 4.6 \\
\hline Mother 5 & $3.4^{\mathrm{ab}}$ & 0.14 & $10.8^{\mathrm{a}}$ & 0.4 & $10.6^{\mathrm{a}}$ & 0.5 & $6.1^{\mathrm{b}}$ & 1.4 \\
\hline Mean & 3.43 & 0.31 & $9.64^{\mathrm{a}}$ & 1.91 & $8.78^{\mathrm{b}}$ & 2.18 & $7.64^{\mathrm{c}}$ & 1.76 \\
\hline
\end{tabular}

SD: Standard deviation, mean counts of the different LAB having the same letter indicated that there is no significant difference $(\mathrm{P}>0.05)$ 


\section{S. AKA-GBEZO et al. / Int. J. Biol. Chem. Sci. 11(6): 2616-2629, 2017}

Table 3: Inhibition zones of test LAB on indicator strains by agar well diffusion method when cell-free supernatants were not neutralized, neutralized and neutralized supernatants treated with catalase and proteinase $\mathrm{K}$ and their number.

\begin{tabular}{|c|c|c|c|c|c|c|c|c|c|c|c|}
\hline \multirow{3}{*}{$\begin{array}{l}\text { Indicator bacteria } \\
\text { B. subtilis CIP } 7718\end{array}$} & \multicolumn{4}{|c|}{ Unneutralized cell-free supernatants } & \multicolumn{4}{|c|}{ Neutralized cell-free supernatants } & \multicolumn{3}{|c|}{$\begin{array}{l}\text { Neutralized supernatants treated with } \\
\text { catalase and proteinase } K\end{array}$} \\
\hline & \multicolumn{3}{|c|}{ Inhibitory spectrum } & \multirow{2}{*}{$\begin{array}{l}\text { LABn } \\
8\end{array}$} & \multicolumn{3}{|c|}{ Inhibitory spectrum } & \multirow{2}{*}{$\begin{array}{l}\text { LABn } \\
0\end{array}$} & \multirow{2}{*}{$\begin{array}{l}\text { Catalase } \\
-\end{array}$} & \multirow{2}{*}{$\begin{array}{l}\text { Proteinase K } \\
-\end{array}$} & \multirow{2}{*}{$\begin{array}{l}\mathbf{L A B n} \\
0\end{array}$} \\
\hline & $+(6)$ & $++(1)$ & $+++(1)$ & & - & - & - & & & & \\
\hline B. cereus DSM $31^{\mathrm{T}}$ & $+(6)$ & - & $+++(1)$ & 7 & - & - & - & 0 & - & - & 0 \\
\hline B. thuringensis DSM $2046^{\mathrm{T}}$ & $+(6)$ & $++(2)$ & $+++(3)$ & 11 & $+(1)$ & $++(1)$ & - & 2 & - & - & 0 \\
\hline S. aureus ATCC 481 & $+(9)$ & $++(2)$ & $+++(2)$ & 13 & - & - & $+++(1)$ & 1 & - & - & 0 \\
\hline S. aureus ATCC 25923 & $+(8)$ & $++(1)$ & $+++(3)$ & 12 & $+(1)$ & - & $+++(1)$ & 2 & - & - & 0 \\
\hline L. innocua ATCC 33090 & $+(9)$ & $++(2)$ & $+++(2)$ & 13 & $+(3)$ & $++(2)$ & $+++(2)$ & 7 & $++(4)$ & - & 4 \\
\hline E. faecalis CIP 105042 & $+(4)$ & $++(1)$ & $+++(4)$ & 9 & $+(1)$ & $++(1)$ & $+++(4)$ & 6 & $++(4)$ & - & 4 \\
\hline E. faecalis & $+(4)$ & $+(1)$ & $+++(4)$ & 9 & $+(1)$ & $++(1)$ & $+++(4)$ & 6 & $++(4)$ & - & 4 \\
\hline E. faecium ATCC 51558 & $+(4)$ & $+(1)$ & $+++(4)$ & 9 & $+(1)$ & $++(1)$ & $+++(4)$ & 6 & $++(4)$ & - & 4 \\
\hline Streptococcus $s p$ & $+(6)$ & $++(3)$ & $+++(4)$ & 13 & $+(6)$ & $++(3)$ & $+++(4)$ & 13 & $++(4)$ & - & 4 \\
\hline L. delbrueckii F/31 & $+(8)$ & $++(3)$ & $+++(4)$ & 15 & $+(6)$ & $++(3)$ & $+++(4)$ & 13 & $++(4)$ & - & 4 \\
\hline S. typhi ATCC 5066 & $+(14)$ & $++(3)$ & $+++(3)$ & 20 & $+(2)$ & - & - & 2 & - & - & 0 \\
\hline S. typhi ATCC 50157 & $+(14)$ & $++(4)$ & $+++(2)$ & 20 & $+(2)$ & $++(1)$ & - & 3 & - & - & 0 \\
\hline E. coli ATCC 28170 & $+(15)$ & $++(3)$ & $+++(2)$ & 20 & $+(4)$ & $++(2)$ & - & 6 & - & - & 0 \\
\hline E. coli ATCC 25922 & $+(16)$ & $++(2)$ & $+++(2)$ & 20 & $+(2)$ & $++(1)$ & - & 3 & - & - & 0 \\
\hline P. aeruginosa & $++(9)$ & $++(2)$ & $-(0)$ & 11 & - & - & - & 0 & - & - & 0 \\
\hline P. aeruginosa ATCC 27853 & $+(10)$ & $+(1)$ & $-(0)$ & 11 & - & - & - & 0 & - & - & 0 \\
\hline
\end{tabular}




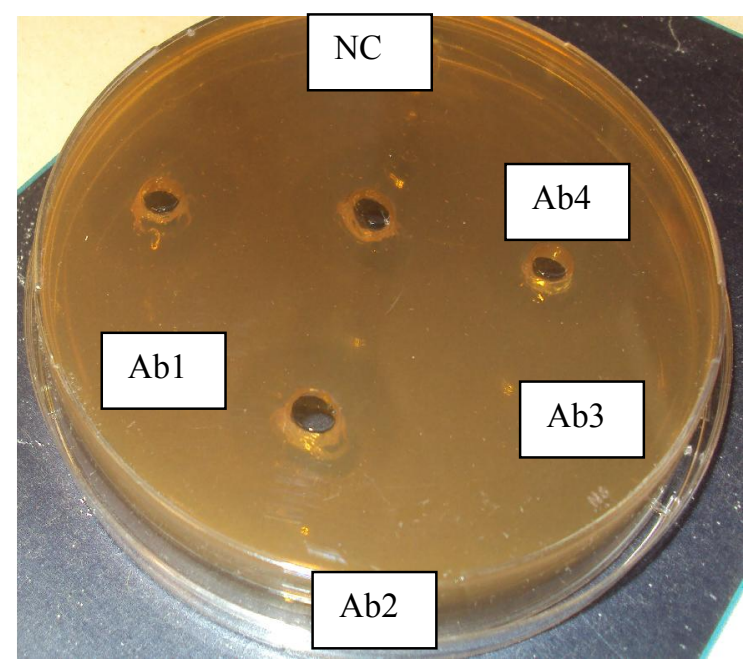

Figure 1: Inhibition of $L$. delbrueckii $\mathrm{F} / 31$ by neutralized cell-free supernatants of LAB strains isolated into anango baca slurry. NC: negative control.

$\begin{array}{lllllllllllllll}1 & 2 & 3 & 4 & 5 & 6 & 7 & 8 & 9 & 10 & 11 & 12 & 13 & 14\end{array}$
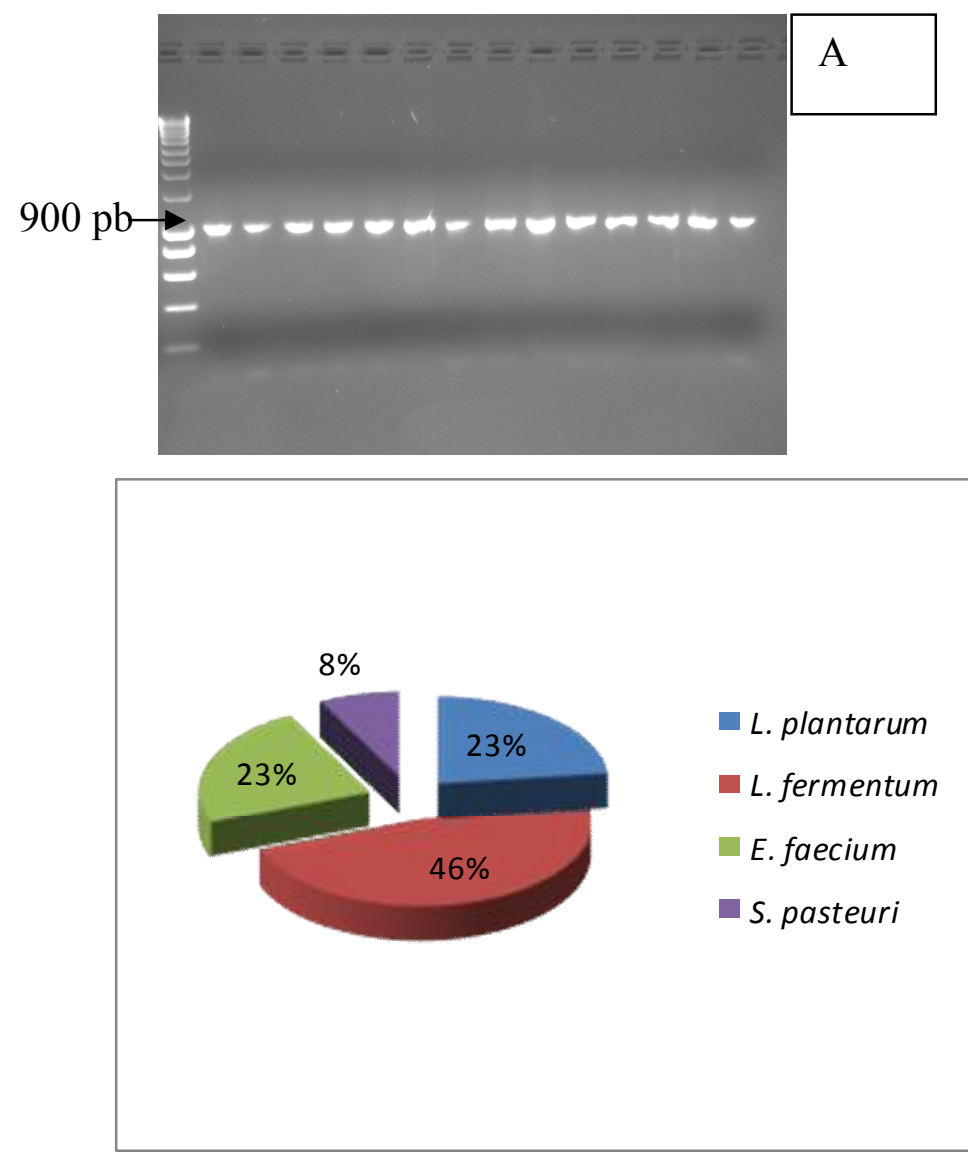

$\mathrm{B}$

Figure 2: Lactic acid bacteria species producing antibacterial activity found into anango baca slurry. A: gel electrophoresis of PCR products using primers 27F and WLAB2R. lane 1: $15000 \mathrm{bp}$ DNA molecular weight marker; lanes 2-14: PCR products; B: percentage of species LAB of anango baca slurry samples. 
Biplot (axes F1 and F2: 99,38\%)

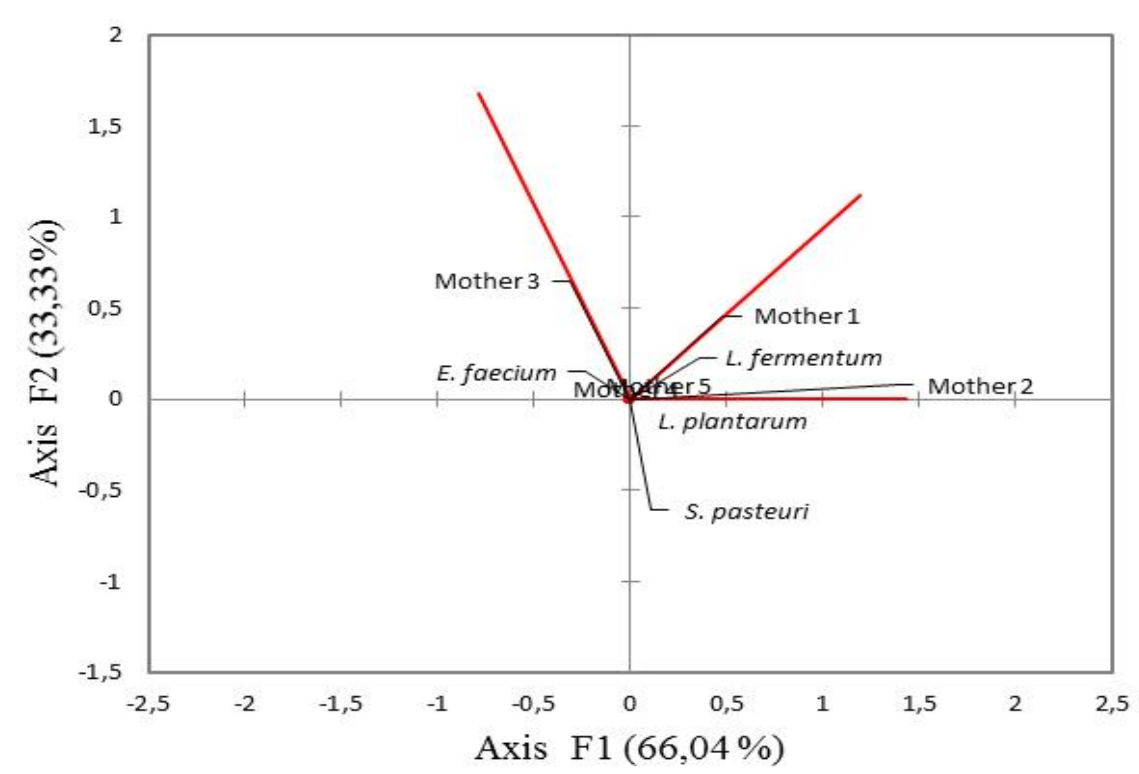

Figure 3: Principal Component Analysis (PCA) indicating the distribution of the $13 \mathrm{LAB}$ species having inhibitory activity against indicators isolated into anango baca slurry samples according to the five mothers.

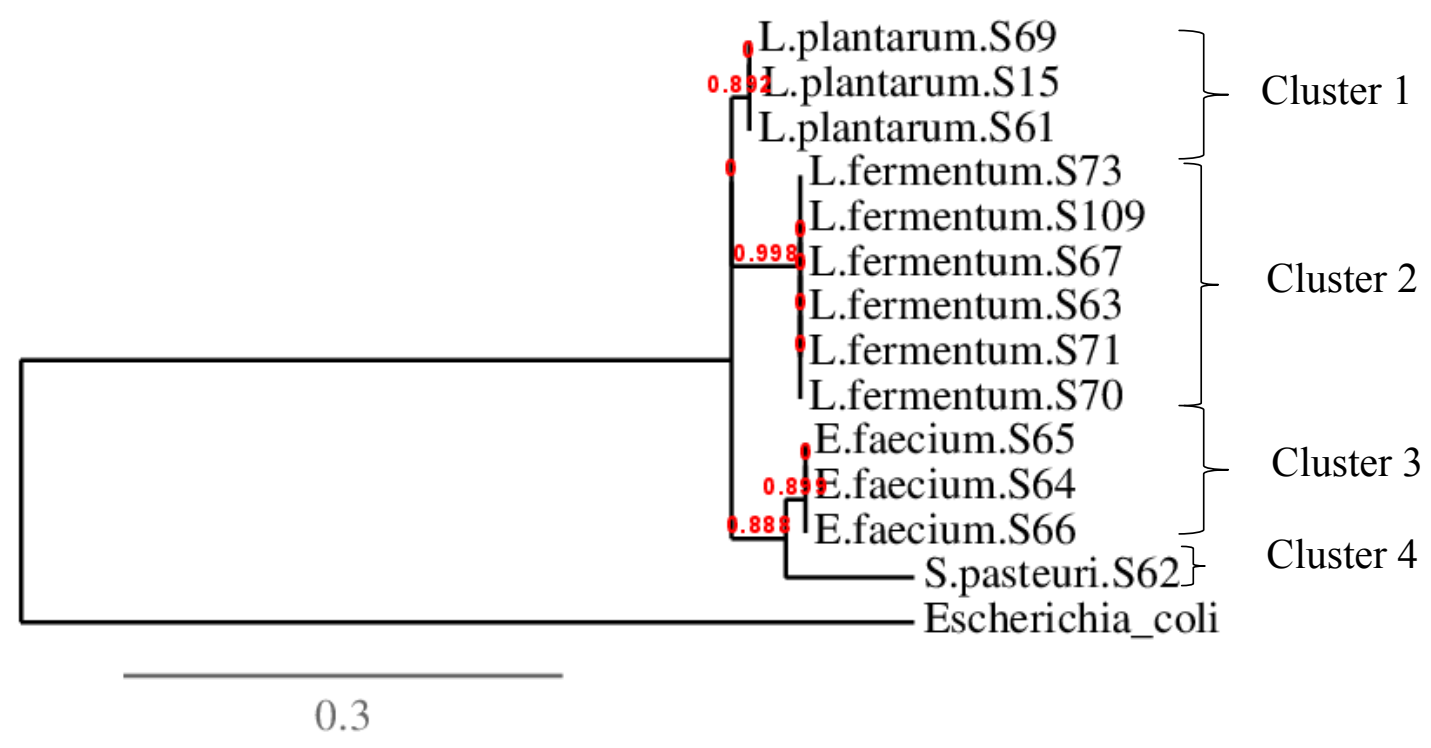

Figure 4: Phylogenetic tree of LAB species based on the 16S rRNA gene sequences. Sequences were aligned with MUSCLE, then curated using Gblocks. A maximum likelihood tree was generated by PhyML using the GTR substitution model and allowing 4 rate substitution categories. Confidence values for the branching order were generated by bootstrapping (based on 100 replications). The number at the nodes indicates the bootstrap values. The scale bar indicates 1 nucleotide substitution per 100 nucleotides. 


\section{DISCUSSION}

The low pH of anango baca slurry samples is likely due to the utilization of free sugars by LAB and is also seen during the production of $o g i$, a similar product to anango baca produced in Nigeria, where the $\mathrm{pH}$ of fermenting maize grains dropps to 3.8 at end of the $72 \mathrm{~h}$ fermentation period (Oyedeji et al., 2013). Similarly, for akamu, a Nigerian fermented maize food, the $\mathrm{pH}$ ranges from 3.22 to 3.95 (Obinna-Echem et al., 2013). In anango baca, LAB are responsible for primarily producing lactic acid, which is a common characteristic of the fermentation of cereal foods (Adebayo and Aderiye, 2007; Omemu, 2011; Wakil and Osamwonyi, 2012). The produced acids play a major role in the reduction of the $\mathrm{pH}$ in the medium, thereby making it acidic. The acidic medium is therefore responsible for the inhibitory effects against pathogens and spoilage bacteria as well as for the improved microbiological stability and safety of the food product (Wakil and Osamwonyi, 2012).

Many authors have used agar spot method to demonstrate antimicrobial activity of LAB against one or more of indicator spoilage or food borne pathogens (Lei and Jacobsen, 2004; Kivanç et al., 2011; Okpara et al., 2014). The fact that the 47 isolates also exhibited some inhibitory activity against indicator strains when the $\mathrm{pH}$ of the medium was not neutralized, might be due to the presence and activity of various antimicrobial compounds such as organic acids by decreased $\mathrm{pH}$ levels (Wakil and Osamwonyi, 2012; Gaamouche et al., 2014). Inhibition of the growth of indicator strains by organic acids production is a common phenomenon observed during lactic acid fermentation. This is a desirable effect because the growth of these bacteria could produce an unpleasant flavour for fermented foods (Adebayo and Aderiye, 2007). After eliminating organic acid function ( $\mathrm{pH}$ was neutralized), the antibacterial activity of LAB CFSs was probably due to the production of hydrogen peroxide. After catalase treatment, the inhibitory effect was due to the production of bacteriocins and/or bacteriocin-like substances. Indeed, LAB have been reported to release other antimicrobial agents, besides organic acid such as hydrogen peroxide, diacetyl and bacteriocin into the medium during food fermentation. These antimicrobial agents have been used to control the growth of pathogens and spoilage microorganisms in food products as well as to help extend their shelf life (Adebayo and Aderiye, 2007; Falegan et al., 2014). Gram-negatif indicators resisted to inhibitory effect of these bacteriocins whereas Gram-positive indicator strains were much more sensitive to tested LAB strains bacteriocins. These results indicate that tested LAB produced bacteriocins which found to be inhibitory towards closely related species including pathogens (Kivanç et al., 2011; Okpara et al., 2014). This can be explained by the presence of lipopolysaccharides in Gram-negative bacteria membrane that may protect their membrane (Gaamouche et al., 2014).

The LAB having inhibitory activity against indicators were L.fermentum, $L$. plantarum, E. faecium and Staphylococcus pasteuri. Falegan et al. (2014), by phenotypic methods, have also identifed $17 \mathrm{LAB}$ isolated from ogi, a similar product produces in Nigeria as $L$. acidophilus, $L$. plantarum, $L$. fermentum, L. brevis and L. bulgaricus with a predominance of $L$. acidophilus. This species difference could be explained by the geographical distance, the environment in which these two products were produced and the methods used to identify isolates. These bacteria have antibacterial activity against $E$. coli pathogen unlike our strains. But our findings are similar to those of Wakil and Osamwonyi (2012) who also isolated and identified $\mathrm{LAB}$ of the fermenting millet gruel from Nigeria as being $L$. plantarum, $L$. fermentum, $L$. meseteriodies, $L$. jensenii, $L$. brevis, P. acidilactici and Lactobacillus spp. with the predominance of $L$. plantarum. These isolates were able to inhibit the growth of various indicator organisms such as E. coli, $S$. aureus, B. cereus, Salmonella spp., $P$. aeruginosa, and $P$. syringae by the production 
of lactic acid, hydrogen peroxide and diacetyl. But, these isolates do not produce bacteriocins. Moreover, Obinna-Echem et al. (2013) used PCR-DGGE to analyse traditional akamu samples. His study revealed that LAB communities are dominated by $L$. fermentum, L. plantarum, L. delbrueckii subsp. bulgaricus and L. helveticus.

Whereas, L.fermentum and L. plantarum are commonly found in products like anango baca slurry, such as ogi (Adebayo and Aderiye, 2007), koko (Lei and Jacobsen, 2004), akamu (Obinna-Echem et al., 2013), a few authors have reported finding E. faecium in african fermented cereal products (Yousif et al., 2005; Franz et al., 2014). On the other hand, E. faecium is isolated from other fermented products particularly milk and meat products such as the nunu, a ghanaian fermented milk product (Akabanda et al., 2013), argentinian artisanal cheese (Suárez et al., 2013), alheira a Portuguese traditional fermented meat product (Barbosa et al., 2014). E. faecium is also found in a traditional brine table olive (Gaamouche et al., 2014). Some strains of this E. faecium have antimicrobial agents which inhibit pathogens and spoilage food-borne bacteria (Yousif et al., 2005; Gaamouche et al., 2014). However, some strains of E. faecium are considered to be opportunistic pathogens. They are sometimes associated with endocarditis, bacteraemia, nosocomial and urinary tract infections (Yousif et al., 2005; Khan et al., 2010).

Only S. pasteuri isolated from anango baca slurry produced also bacteriocins. This coagulase-negative, Gram-positive bacterium of the Staphylococcaceae family has been the subject of several studies. Some authors have indicated that S.pasteuri showed antimicrobial activity against various antibiotic resistant S. aureus and Listeria monocytogenes, two food-borne pathogens (Hong et al., 2014). But S. pasteuri has widespread distribution in food and in the environment, and may represent a relevant antibiotic resistance reservoir, mainly in habitats with restrictive conditions and reduced staphylococcal diversity (Faria et al., 2009; Marino et al., 2010).

\section{Conclusion}

The anango baca slurry contained a considerable amount of LAB. Some of these LAB had the ability to produce antibacterial substances to inhibit the growth of pathogens and food-borne spoilage bacteria. These bacteria were L.fermentum, L.plantarum, E. faecium and S. pasteuri, with L. fermentum as predominant species. However, E. faecium and S. pasteuri, which produced bacteriocins, are considered sometimes to be opportunistic pathogens. Thus further studies are required to select LAB able to be used as starters to improve the hygiene and safety of anango baca slurry, to improve children health and also as probiotic in infant formulas.

\section{COMPETING INTERESTS}

The authors declare that they have no competing interests.

\section{AUTHORS' CONTRIBUTIONS}

GAK and BB defined the subject; SA and PA carried out the studies and acquired results; SA and MN analyzed the data; SA drafted the manuscript for publication. The draft was read and corrected and finalized by GAK, RK-N, MK-C and BB. All the authors read and approved the final manuscript.

\section{ACKNOWLEDGMENTS}

The authors would like to express their sincere gratitude to the mothers from whom anango-baca slurry have been collected. The authors would also like to thank Jasmina Saric for her review and editing contribution.

\section{REFERENCES}

Achi OK, Ukwuru M. 2015. Cereal-based fermented foods of Africa as functional foods. Int. J. Microbiol. App., 2(4): 7183.

http://www.openscienceonline.com/journ al/ijma

Adebayo CO, Aderiye BI. 2007. Ecology and antibacterial potential of lactic acid 
bacteria associated with fermented cereals and cassava. Res J Microbiol, 2(5): 426-435. DOI: 10.3923/jm.2007.426.435

Akabanda F, Owusu-Kwarteng J, TanoDebrah K, Glover RLK, Nielsen DS, Jespersen L. 2013. Taxonomic and molecular characterization of lactic acid bacteria and yeasts in nunu, a Ghanaian fermented milk product. Food Microbiol., 34(2): 277-283. DOI: 10.1016/j.fm.2012.09.025

Barbosa J, Borges S, Teixeira P. 2014. Selection of potential probiotic Enterococcus faecium isolated from Portuguese fermented food. Int. J. Food Microbiol., 191: 144-148. DOI: 10.1016/j.ijfoodmicro.2014.09.009.

Butler CC, Duncan D, Hood K. 2012. Does taking probiotics routinely with antibiotics prevent antibiotic associated diarrhoea? $B M J$, 344: 1-4. DOI: https://doi.org/10.1136/bmj.e682

Castresana J. 2000. Selection of conserved blocks from multiple alignments for their use in phylogenetic analysis. Molecular Biol. Evolution, 17(4): 540-552.

Edgar RC. 2004. MUSCLE: multiple sequence alignment with high accuracy and high throughput. Nucl. Acids Res., 32(5): $1792-1797 . \quad$ DOI: 10.1093/nar/gkh340

Falegan CR, Akoja SO, Ogunjobi LP, Obaro CE. 2014. Assesment of the antimicrobial activity of cell free crude bacteriocin produced by Lactobacillus species isolated from ogi (fermented maize) on Escherichia coli a food borne pathogen. US Open General Microbiol. J., $\quad \mathbf{1}(2)$ : $1-8$. http://arepub.com/Journals.php

Faria C, Vaz-Moreira I, Serapicos E, Nunes OC, Manaia CM. 2009. Antibiotic resistance in coagulase negative Staphylococci isolated from wastewater and drinking water. Sci. Total. Environ., 407(12): $\quad 3876-3882$. DOI: 10.1016/j.scitotenv.2009.02.034
Franz CMAP, Hucha M, Mathara JM, Abriouel H, Benomar N, Reid G, Galvez A, Holzapfel WH. 2014. African fermented foods and probiotics. Int. J. Food Microbiol., 190: 84-96. DOI: 10.1016/j.ijfoodmicro.2014.08.033

Gaamouche S, Arakrak A, Bakkali M, Laglaoui A. 2014. Antimicrobial activity of lactic acid bacteria and bacteriocins isolated from a traditional brine table olives against pathogenic bacteria. Int. J. Curr. Microbiol. App. Sci., 3(11): 657666.

Guindon S, Dufayard JF, Lefort V, Anisimova M, Hordijk W, Gascuel O. 2010. New algorithms and methods to estimate maximum-likelihood phylogenies: assessing the performance of PhyML 3.0. Systematic Biol., 59(3): 307-321. DOI: $10.1093 /$ sysbio/syq010

Henk E, Dietrich M, Weese T. 2008. Identification of Lactic Acid Bacteria in Michigan Cherry Wines. Stud. Sum. Schol., $\quad$ Paper 2. http://scholarworks.gvsu.edu/sss/2

Hong J, Quan LH, Heu S, Jung KS, Han S-W, Moon E, Roh E. 2014. A new antimicrobial substance produced by Staphylococcus pasteuri isolated from vegetables. Food Sci. Biotechnol., 23(3): 983-990. DOI: 10.1007/s10068-0140133-1

Khan H, Flint S, Yu P-L. 2010. Enterocins in food preservation. Int. J. Food Microbiol., 141(1-2): 1-10. DOI: 10.1016/j.ijfoodmicro.2010.03.005

Kivanç M, Yilmaz M, Çakir E. 2011. Isolation and identification of lactic acid bacteria from boza and their microbial activity against several reporter strains. Turk. J. Biol., 35(3): 313-324. DOI: 10.3906/biy0906-67

Kouakou EKV, Bouafou KGM, Meite A, Kouame KG, Kati- Coulibaly S 2016. Farine de sevrage commerciale anagobaka: quels risques pathologiques dans le régime du rat en croissance? Int. J. Biol. Chem. Sci., 10(1): 167-174. http://ajol.info/index.php/ijbcs 
Lei V, Jakobsen M. 2004. Microbiological characterization and probiotic potential of koko and koko sour water, African spontaneously fermented millet porridge and drink. J. Appl. Microbiol., 96(2): 384-397. DOI: $10.1046 / \mathrm{j} .1365-$ 2672.2004.02162.x

Lopez I., Ruiz-Larrea F, Cocolin L, Orr E, Phister T, Marshall M, VanderGheynst J, Mills D.A. 2003. Design and evaluation of PCR primers for analysis of bacterial populations in wine by denaturing gradient gel electrophoresis. Appl. Environ. Microbiol., 69(11): 6801-6807. DOI: $\quad$ 10.1128/AEM.69.11.68016807.2003

Marino M, Frigo F, Bartolomeoli I, Maifreni M. 2010. Safety-related properties of Staphylococci isolated from food and food environments. J. Appl. Microbiol., 110(2): 550-561. DOI: 10.1111/j.13652672.2010.04909.x

Obinna-Echem PC, Kuri V, Beal J. 2013. Evaluation of the microbial community, acidity and proximate comosition of akamu, a fermented maize food. J. Sci. Food Agric., 94(2): 331-340. DOI: $10.1002 /$ jsfa. 6264

Okpara AN, Okolo BN, Okolo BN, Ugwuanyi JO. 2014. Antimicrobial activities of lactic acid bacteria isolated from akumu and kunun-zaki, (cereal based nonalcoholic beverages) in Nigeria. Afr. J. Biotechnol., 13(29): 2977-2984. DOI: 10.5897/AJB12.376
Oyedeji O, Ogunbanwo ST, Onilude AA. 2013. Predominant lactic acid bacteria involved in the traditional fermentation of $f u f u$ and ogi, two nigerian fermented food products. Food Nutr. Sci., 4(11A): 40-46. DOI: 10.4236/fns.2013.411A006

Soro-Yao AA, Brou K, Koussémon M, Djè KM. 2014. Proximate composition and microbiological quality of millet gruels sold in Abidjan (Côte d'Ivoire). Int. J. Agric. Inno. Res., 2(4): 2319-1473.

Suárez NE, Saavedra L, Složilová I, Bonacina J, Demnerová K, Sesma F. 2013. Draft genome sequence of Enterococcus faecium strain CRL 1879, isolated from a northwestern Argentinian artisanal cheese. Genome A., 1(4): 1-2. DOI: $10.1128 /$ genomeA.00514-13

Wakil SM, Osamwonyi UO. 2012. Isolation and screening of antimicrobial producing lactic acid bacteria from fermentating millet gruel. Int. Res. J. Microbiol., 3(2): 72-79.

Yousif NMK, Dawyndt P, Abriouel H, Wijjaya A, Schillinger U, Vancanneyt M, Swings J, Dirar HA, Holzapfet WH, Franz MAP. 2005. Molecular characterization, technological properties and safety aspects of Enterococci from "Hussuwa", an African fermented sorghum product. J. Appl. Microbiol., 98(1): 216-228. DOI: $10.1111 / \mathrm{j} .1365-$ 2672.2004.02450.x. 